\title{
Analisa Penegakan Hukum dan Pengawasan Keimigrasian pada Kasus Masuknya Warga Negara China Ditengah Masa Pandemi Covid-19
}

\author{
Muhammad Fachryza*, Muhammad Faiz Febriandana, Yofan Gusti Pratama \\ Politeknik Imigrasi (Badan Penelitian dan Pengembangan Hukum dan HAM) \\ Jl. Raya Gandul No. 4, Cinere, Depok 16512 \\ *Correspondence email: mfaiz010207@gmail.com
}

\begin{abstract}
Abstrak. Petugas imigrasi selama mengimplementasikan fungsi serta tugas menjaga gerbang negara memiliki peran yang begitu penting dalam situasi penyebaran virus covid-19 di dunia. Imigrasi menganut empat fungsi keimigrasian, yaitu pelayanan, kemanan, penegakan hukum, dan fasilitator pembangun negara. Pada karya tulis ilmiah bertemakan tentang analisis penegakan hukum dan pengawasan keimigrasian dengan studi kasus masuknya warga negara china ditengah masa pandemic covid- 19 . dimana penegakan hukum dan pengawasan orang asing dimasa pandemic saat ini sangatlah riskan dikarenakan akan memiliki sejumlah perbedaan dimana dalam masa sulit ini atau dalam masa adaptasi New Normal di Indonesia keimigrasian sejatinya dapat mengembangkan dan menyesuaikan di dalam penegakan hukum baik terhadap WNI maupun Orang Asing. Pemerintah sendiri berkerjasama dengan Direktorat Jenderal Imigrasi memberikan peraturan dan kebijakan baru terkait pelaksanaan tugas dan fungsi pokok keimigrasian, termasuk di dalamnya penegakan hukum. Karya ilmiah ini bertujuan untuk memberikan penjelasan terkait penegakan hukum keimigrasian serta pengawasan orang asing yang dilakukan selama masa pandemic Covid-19 ini, dan juga didasari dari kebijakan-kebijakan pemerintah Indonesia khususnya keimigrasian dalam pencegah penyebaran Covid-19.
\end{abstract}

Kata kunci: Hukum Keimigrasian; Penegakan Hukum; Pengawasan; Masa Pandemic; Covid-19

\begin{abstract}
Immigration officers while implementing their functions as well as state gatekeepers have a very important role in the situation of the spread of the covid-19 virus in the world. Immigration has four functions of immigration, namely service, security, law enforcement, and facilitator for state development. In a scientific paper with the theme of analysis of law enforcement and immigration control with case studies of the entry of Chinese nationals in the midst of the COVID-19 pandemic. where law enforcement and supervision of people during the current pandemic is very risky because it will have a number of differences where in this difficult time or in the New Normal adaptation period in Indonesia, immigration can actually develop and adjust in law enforcement both Indonesian citizens and foreigners. The government itself, in collaboration with the Directorate General of Immigration, provides new regulations and policies relating to the implementation of the main duties and functions of immigration, including including law. This scientific work aims to provide an explanation regarding immigration law enforcement and the supervision of foreigners carried out during the Covid-19 pandemic, and is also based on Indonesian government policies, especially immigration in preventing the spread of Covid-19.
\end{abstract}

Keywords: Immigration Law; Law Enforcement; Supervision; Pandemic Period; Covid-19

\section{PENDAHULUAN}

Covid-19 sendiri pertama kali terjadi di Negara China tepatnya di daerah Wuhan pada akhir 2019 lalu dan telah memicu pandemi global. Virus ini mendadak menjadi momok mengerikan bagi seluruh dunia. Bahkan World Health Organization atau yang disingkat WHO, pada awal Desember telah memperingatkan ke seluruh dunia bahwa Covid-19 ditetapkan sebagai Public Health Emergency. Awal merebaknya virus covid-19 di Wuhan, Badan Kesehatan WHO dengan tegas menginstruksikan kepada negara-negara dunia bahwa virus covid-19 ini memiliki berpotensi besar menjadi sumber virus yang dapat menyebar dengan cepat. Penyebaran virus ini terjadi antara manusia secara cepat dan meluas. Kini, tingkat penyebaran Covid-19 yang bisa dikatakan sangat luar biasa cepatnya. Dan Badan Kesehatan dunia World Health Organization Pada 11 Maret 2020 telah menetapkan Covid-19 sebagai pandemi dunia. Di Indonesia sendiri Covid-19 masuk pada bulan Maret 2020 (Pitaloka at al., 2020)
Saat ini muncul epidemi baru yang bermunculan dari sebuah virus yaitu virus corona, virus dengan diagnosis mulai dari gejala berat hingga ringan. Penyakit Coronavirus (COVID-19) adalah jenis virus baru yang belum teridentifikasi dalam tubuh manusia. Gejala COVID-19 umumnya terdeteksi dalam 2 hari hingga 2 minggu setelah terinfeksi. Gejala umum virus corona adalah sesak napas seperti demam, batuk. Di sauatu kasus gejala bisa menimbulkan peneunomia dan sesak nafas akut, gagal ginjal, sampai meninggal. Berita COVID-19 di Indonesia hingga empat belas april masih menunjukkan kenaikan yang cukup tinggi pada total orang yang terinfeksi sebanyak 4.839 dengan 282 kasus baru, 426 pasien pulih dan 459 kematian (Kemenkes RI, 2020).

Penyebaran Virus korona di Indonesia dengan jumlah gejala dan / atau meninggal yang naik dan melebar di semua bagian negara dan wilayah, sosial budaya, perekonomian, pertahanan dan keamanan. Setelah itu, virus corona muncul dan berdampak besar di 
berbagai daerah. Salah satu sektor yang terpengaruh dan dirasakan adalah sektor imigrasi, khususnya dalam penegakan hukum dan pengawasan. Sebagai promotor dan penjaga kedaulatan negara, para imigran tentunya harus melayani warganya.

Tidak hanya WNI melainkan juga WNA, Pelayanan bagi WNA sejatinya imigrasi harus berjalan sebagaimana mestinya saat sebelum adanya pandemic covid-19, namun dengan cara yang berbeda yaitu dengan menerapkan protokol kesehatan. Sehingga, warga negara Indonesia maupun orang asing dilayani dengan aman dan baik dari segi pelayanan keimigrasiannya harus dikontrol. Dan imigrasi dapat tetap melaksanakan tugasnya sebagai fasilitator pembangunan dan penjaga kedaulatan. Dimana kedaulatan merupakan hal utama dalam berdirinya suatu negara, salah satu bentuk penjagaan kedaulatan adalah dengan penegakan hukum bagi seluruh WNI maupun WNA yang berada di NKRI. Karena seluruh WNA di Indonesia harus tetap diawasi oleh imigrasi untuk menjaga kedaulatan negara dan menegakkan hukum. Akibat adanya covid-19 ini maka tantangan imigrasi dalam pelaksanaan serta pengawasan dan tindakan hukum kepada WNA akan lebih sulit. Dikarenakan terdampak wabah covid-19 ini. Dalam karya tulis ilmiah ini akan dibahas bagaimanakah penerapan atau implementasi Penegakan Hukum dan Orang Asing dalam masa pandemic dari sisi keimigrasian.

Dalam penegakan Hukum dan mengawasi terhadap WNA dan juga WNI Imigrasi haruslah menerapkan protocol Kesehatan untuk mengurangi infeksi virus virus di negara indonesia. Dalam pengawasan dan penegakan hukum imigrasi harus tetap menjalankan sebagaimana mestinya,dikarenakan masa pandemic covid-19 seperti sekarang ini dapat di manfaatkan oleh sekelompok/seorang dalam melakukan pelanggraan khususnya pelanggaran Keimigrasian.Hal ini bertujuan untuk menjaga kedaulatan dengan mengedepankan kualitas keamanan Kesehatan dan kualitas dalam penegakan hukum terhadap kontrol WNI maupun WNA sehingga imigrasi dapat tetap melaksanakan tugasnya sebagai fasilitator pembangunan dan penjaga kedaulatan. Dari latarbelakang diatas maka akan dibahas bagaimana pelaksanaan penegakan hukum dan pengawasan keimigrasian terhadap orang asing di dalam masa kenormalan baru dengan studi kasus dari kasus masuknya warga china ke Indonesia ditengah masa pandemic covid-19, Dimana kita ketauhi imigrasi merupakan salah satu yang berperan menjaga kedaulatan, hal yang paling utama dalam berdirinya suatu bangsa/ negara, salah satu bentuk penjagaan kedaulatan adalah dengan penegakan hukum bagi WNI dan juga WNA yang sedang berada di negara indonesia.

\section{METODE}

Dalam penulisan ini, penulis memutuskan menggunakan metode analisis deskriptif kualitatif terkait dengan upaya pembangunan hukum di bidang keimigrasian dalam rangka penegakan hukum dan pengawasan keimigrasian pada kasus masuknya warga negara China pada masa pandemi Covid 19. Metode analisis deskriptif dilakukan dengan cara mendeskripsikan proses penegakan hukum serta pelaksanaan pengawasan di masa pandemi. Dalam hal ini penulis akan mendeskripsikan hasil penelitian melalui beberapa sumber dan mengambil kesimpulan dari beberapa artikel maupun jurnal terkait.

\section{HASIL DAN PEMBAHASAN}

\section{Penegakan Hukum Dan Pengawasan Orang Asing}

Penegakan hukum merupakan suatu proses dimana kemauan hukum menjadi nyata. Lalu dengan kemauan hukum ialah pemikiran lembaga legislatif sebagaimana tertuang dalam ketentuan hukum. Dalam penegakan hukum, terdapat hal yang dapat terpengaruh. Penegakan hukum dipandang hanya sekedar menjalankan hukum, padahal trend di Indonesia sangat terkenal sehingga penegakan hukum sangat terkenal. Selain itu, terdapat kemungkinan yang kuat untuk memaknai penegakan hukum sebagai sebuah pelaksana putusan hakim (Soerjono, 2014).

Imigrasi merupakan garda pertama sebagai pintu gerbang negara dalam penegakan kedaulatan. Imigrasi Indonesia memiliki 2 tindakan penegakan hukum yang dimana hal tersebut dapat mengadili pelaku pelanggar keimigrasian. Adapun 2 tindakan Hukum Keimigrasian bagi pelanggar Hukum Keimigrasian diatur UU No.6 Tahun 2011 yang berbunyi :

1. Tindak pidana seperti penyidikan keimigrasian yang menjadi bidang dari sejumlah system peradilan pidana terintegrasi, system peradilan pidana misalnya menyelundupkan narkoba, menyelundupkan senjata; dan yang lain-lain.

2. Tindak administratif seperti tindakan adminsitratif dalam bidang imigrasi adalah tindakan administratif di bagian keimigrasian selain system peradilan, tindakan keimigrasian tersebut antara lain deportasi kepada WNA agar keluar dari negara dan zona yurisdiksi negara misalnya tidak sahnya izin tinggal, izin tinggal kadaluarsa, perdagangan manusia dan lain sebagainya.

Selain melalui Tindakan hukum tersebut Keimigrasian juga mengawasi WNA yang akan memasuki NKRI dengan melakukan kebijakan selective Policy/kebijakan selektif yang dimana petugas Imigrasi memfilter Bagi setiap WNA yang keluar masuk wilayah negara Indonesia, dimana hanya WNA yang memiliki manfaat dan yang tidak membahayakan dan tertib dengan peraturan yang ditetapkan negara yang diperbolehkan masuk dan keluar wilayah negara.

Hak-hak dan otoritas seluruh negara-negara guna menegakkan yurisdiksi untuk orang, objek, dan tindakan yang terjadi di negara-negara tersebut didasarkan dengan 
hukum internasional. Artinya setiap negara berhak merumuskan masalah transportasi lintas negara, baikpun itu penduduk, barang ataupun tindakan dimana dapat terjadi di wilayahnya. imigrasi mengacu pada bidang mengatur pindahnya penduduk lintas negara ke negara lain, dan legal di semua negara yang mempunyai ciri umum atau khusus tiap-tiap negara sejalan pada nilai serta kebutuhannya. didasarkan aturan umum Germ Migration sebagaimana diatur dalam UU No 6 Tahun 2011 tentang Keimigrasian yang intinya imigrasi adalah urusan lalulintas penduduk atau orang yang masuk atau keluar wilayah Indonesia dan pemantauannya guna menegakkan penegakan hukum. kedaulatan negara."

Karenanya setiap negara yang melarang atau melarang siapa pun memasuki atau meninggalkan negara itu. Berdasarkan persepsi universal ini, keberadaan aturan keimigrasian merupakan fitur yang sangat penting untuk kepatuhan terhadap hukum nasional di wilayah negara yang bertanggung jawab, dan siapa pun yang memasuki wilayah suatu negara adalah warga negara. Sebuah negara yang diatur dengan sendirinya.

Dalam pelaksaanaanya imigrasi menjadi garda pertama sebagai pintu gerbang negara dalam penegakan kedaulatan. Imigrasi Indonesia sebagai garda pertama tersebut menerapkan sebuah kebijakan yang dimana juga berfungsi sebagai filter utama dari masuk dan keluarnya warga negara asing yang akan memasuki Indonesia. Yaitu Selective Policy atau kebijakan selektif. Kebijakan selektif atau Selective Policy ialah kebijakan inti pada suatu negara guna mengupayakan terwujudan kedaulatan negara itu serta patut menghormati kebijakan tersebut (Syahrin, 2018). Dengan begitu dapat dikatakan bahwa Selective Policy merupakan bentuk salah satu penegakan hukum dan pengawasan secara awal dari segi dokumen perjalanan maupun wawancara atau Profileing.

Selain melalui pengawasan Selective Policy Pengawasan WNA pada wilayah Indonesia dapat dibagi menjadi dua, berupa pengawasan WNA yang masuk ke Indonesia yang bertempat tinggal diindonesia dan mereka yang akan keluar dari wilayah indonesia. Hal ini memberikan kemungkinan dimana orang asing tersebut menaati aturan yang berlaku dan hukum diindonesia dan kemungkinan orang asing tersebut melakukan pelanggaran jika masih berada diindonesia serta diterima masuk. mengarah ke dua kemungkinan. Menyebabkan masalah imigrasi atau pemerintahan, atau menaati hukum yang berlaku. Dan warga negara asing kebanyakan tidak ada yang tahu hukum dan peraturan mutlak di pemerintah negara. Hal ini menyebabkan problem serta bisa diupayakan secara hukum dengan cara-cara berikut:

1. Tindakan pidana adalah penyidikan keimigrasian bagian dari berbagai sistem peradilan pidana terintegrasi, aturan peradilan pidana (sidik, tuntut, serta peradilan), termasuk perdagangan narkotika, perdagangan orang, dan larangan lainnya.
2. Tindakan administratif berupa TAK. TAK adalah tindakan administratif yang berkaitan dengan keimigrasian yang berada di luar proses peradilan. Undang-undang keimigrasian ini berkaitan dengan deportasi warga negara asing untuk meninggalkan wilayah hukum Republik Indonesia. Misalnya, penyalahgunaan izin tinggal bagi imigran, tempat tinggal, imigran ilegal, dll.

Pengawasan sendiri dibagi menjadi 2 yaitu pengawasan terbuka dan tertutup. Pengawasan secara tertutup biasanya dilakukan untuk mencari informasi dan bukti dengan menerapkan cara inteljen dimana tidak diketahui. Intelijen keimigrasian meripakan serangkaian giat pengumpulan data keimigrasian serta pensterilan daerah atau pengamanan control daerah target yang berguna untuk mendapatkan data guna penyajian informasi dengan analisis untuk menentukan kemungkinan keadaan keimigrasian diatur atau mengatur informasi tersebut.. guna dilaksanakannya tugas Intelijen Keimigrasian, Imigrasi melakukan pengintaian keimigrasian dan penyiapan lapangan dalam bidang keimigrasian serta diberi wewenang untuk memperoleh informasi berasal penduduk sekitar atau lembaga pemerintah, mengunjungi kawasan atau Gedung dimana diyakini keberadaan dan aktivitas WNA, melakukan operasi intelijen imigrasi, mengamankan data dan informasi imigrasi, dan menjamin hak keimigrasian.

\section{Kebijakan Keimigrasian Pada Masa Pandemi}

Sehubungan dengan pandemi Covid 19, fungsi keamanan Warga negara dan indonesia menjadi perhatian utama bagi imigrasi. Keimigrasian memiliki peran penting yang sangat memiliki resiko besar yaitu menjadi penjaga gerbang negara. karena imigrasi adalah lembaga pertama yang menyaring masuk dan keluarnya WNA yang masuk maupun meninggalkan Kawasan NKRI. Pemenuhan jabatan ini dimaksudkan untuk upaya pencegahan dalam rangka tindakan keimigrasian. Pembaruan fitur ini terlihat dari adanya laranganlarangan bagi WNA yang masuk menuju NKRI seperti yang dijelaskan pada Permenkumham 11/2020. Pembatasan pergerakan orang melalui gerbang pengawasan keimigrasi akan dilakukan berpedoman pada Permenkumham 11/2020 yang berlaku mulai dua April 2020 pukul 12.00 WIB sampai waktu yang belum ditentukan.

Akan tetapi, ada pengecualian bagi banyak orang asing dalam peraturan imigrasi dan transit. Ini termasuk KITAS serta KITAP, dan juga kartu izin tinggal diplomatik, serta pemilik izin tinggal resmi. selanjutnya yaitu bantuan medis, makanan serta personel pendukung. Kru untuk transportasi udara, darat maupun laut. WNA yang mengerjakan Projek strategis nasional harus dirawat di rumah sakit dalam kondisi tertentu, termasuk sertifikat kesehatan yang dikeluarkan oleh otoritas kesehatan nasional di daerah atau negara tanpa korona. 
Permenkumham menerapkan sebuah pengaturan untuk WNA yang menetap di NKRI. Pertama, WNA dengan izin tinggal untuk berkunjung bebas visa kunjungan dan visa saat kedatangan dimana Izin WNA tersebut telah kedaluwarsa atau izin tinggal mereka tidak bisa diperpanjang, secara otomatis diberikan izin tinggal tanpa mengajukan permohonan tanpa biaya kekantor. Izin tinggal yang telah habis masa berlakunya maupun belum bisa dilanjutkan, akan ditangguhkan dan diberikan izin tinggal yang secara langsung diberikan dan tidak harus memberikan permohonan kekantor dan tanpa biaya.

Permenkumham 11/2020 dianggap menjadi aturan keimigrasian pada saat darurat Covid-19, sehingga menggantikan peran tupoksi imigrasi normatif dari menjaga kedaulatan menjadi kemanfaatan (Syahrin, 2020) yaitu kebijakan selektif keimigrasian. Selektif dalam hal ini berarti menjaga. Kebijakan selektif ini adalah pelaksanaan wewenang negara terhadap WNA dan WNI yang sedang berada dikawana NKRI pada saat terjadi pandemi. Negara memilik kewajiban pada keselamatan warganya dari campur tangan luar, dalam hal ini penyebaran virus. Selain itu, negara memeiliki kewajiban melindungi hak warga negara Indonesia.

Meskipun diberlakukan secara ketat terhadap WNA yang memasuki wilayah Indonesia, kebijakan imigrasi selama pandemi tidak terlepas dari kewajibankewajiban NKRI sebagai pemproteksi hak-hak penduduk yang tinggal di kawasan NKRI selama covid19. Kewajiban ini diperbarui di surat edaran: IMIGR.01.01-1102 Tahun 2020 tentang Pelayanan Izin Tinggal Keimigrasian di tatanan kenormalan baru, dimana WNA mendapatkan keuntungan yaitu WNA akan mendapatkan izin tinggal selama WNA tersebut belum bisa kembali ke negara asalnya.

\section{Penegakan Hukum Keimigrasian Pada Masa Pandemi}

Penegakan hukum adalah proses upaya tegak dan berfungsinya norma-norma hukum sebagai pedoman perilaku dalam hubungan-hubungan hukum dalam kehidupan bermasyarakat dan bernegara. Dalam menjalankan penegakan hukum dan pengawasan terhadap orang asing imigrasi harus lah berlandaskan peraturan tertulis. Peraturan tertulis yang menjadi landasan Imigrasi Indonesia ialah Undang-Undang no 6 tahun 2011. Peraturan tersebut dapat membuat setiap orang asing memasuki wilayah suatu negara akan tunduk pada hukum negara tersebut sebagaimana halnya warga negara itu sendiri.

Penerapan penegakan hukum keimigrasian pada masa darurat Covid 19 telah mengalami sejumlah perubahan serta dilakukannya penyesuaian dengan tatanan normal baru. Pertama, pengawasan dilakukan secara terbatas karena adanya perubahan waktu kerja pekerja imigrasi. Pengawasan bisnis, rumah dan lain-lain dibatasi, pengawasan menanti pesan dari masyarakat.
Pada masa pandemi, tren pelanggaran keimigrasian menurun sejalan dengan dilakukannya pembatasan ruang gerak keluar masuk wilayah Indonesia.

Kedua, dalam hal tindakan administratif di bidang keimigrasian terdapat keringanan dalam beberapa tindakan, antara lain warga negara tidak memungut biaya melebihi masa tinggal yang diizinkan dan penangguhan deportasi, hal ini berdasarkan ketentuan surat edaran Direktur. Umum untuk Pencegahan dan Pengendalian Penyakit. SR.04.03 / II / 6689/2020 tentang penyelenggaraan angkutan udara dalam rangka mencegah tersebarnya Covid-19 untuk mencegah perjalanan udara sementara ke dan dari Indonesia. Dengan demikian, warga negara praktis tidak dapat kembali ke negara asalnya selama keadaan darurat Covid 19. Ketiga aspek dalam aspek penyelidikan keimigrasian tersebut, sejauh ini belum ada aturan atau SOP yang secara khusus mengatur tentang penyidikan keimigrasian pada saat pandemi. Akibatnya, warga negara asing yang dianggap tidak bertanggung jawab bisa dikeluarkan.

Masalah lain dengan penegakan hukum imigrasi selama pandemi adalah terkait dengan penahanan imigrasi. Belum ada SOP yang tepat terkait penerapan penegakan hukum dan perlindungan di Rutan. Selama pelaksanaan, Rudemin menerapkan protokol kesehatan umum seperti penyemprotan disinfektan, pembersih tangan dan tes cepat untuk narapidana. Namun, hal itu tidak bisa dilakukan secara berkelanjutan mengingat anggaran yang terbatas untuk Rudenim. Selain itu, Rudenim bukan hanya orang asing yang bermasalah, tapi juga pendatang dan pengungsi yang tidak bisa kembali ke tanah air, sehingga warga Rudemin lebih memilih pola pengelolaan konvensional (Suryokumoro, 2020).

\section{Penegakan Hukum Dan Pengawasan Keimigrasian Pada Kasus Masuknya Warga Negara China Ditengah Masa Pandemi Covid-19 \\ Dalam menegakan hukum dan pengawasan} terhadap orang asing,Imigrasi haruslah wajib untuk terus melaksanakan tugasnya dalam menjaga kedaulatan negara begitu juga saat masa pandemic covid 19 ini dimana 153 Warga negara china masuk ke wilayah Indonesia di tengah masa pandemic covid-19.Hal ini bukan lah suatu perbuatan illegal,melainkan bentuk dari pengawasan keimigrasian dari kebijakan selective policy yang dimana sebanyak $153 \mathrm{WNA}$ asal China berjumlah 150 orang menggunakan ITAS dan ITAP, serta 3 orang yang memegang visa diplomatik. Karenanya, mereka medapatkan izin masuk ke Indonesia. "Seluruh penumpang asing (WNA dari China) yang tiba tersebut masuk dalam kategori orang asing yang diizinkan masuk ke Wilayah Indonesia berdasarkan SE Dirjen Imigrasi tentang pembatasan sementara masuknya orang asing ke wilayah Indonesia dalam masa pandemi Covid-19.

Mengenai kasus ini sebelumnya memang pemerintah telah mengeluarkan Surat Edaran (SE) tentang hal ini, Surat tersebut diterbitkan untuk 
memperpanjang masa penerapan protokol kesehatan terhadap seseorang yang akan melakukan perjalanan internasional dengan menambahkan beberapa ketentuan baru yang disertai dengan pemantauan, pengendalian, dan evaluasi untuk mencegah terjadinya peningkatan penularan Covid-19 termasuk untuk varian baru. Kemudian yang didalamnya telah disebutkan dalam bagian Protokol huruf F angka 1 butir c bahwa "Pelaku perjalanan intenasional yang berstatus WNA dari seluruh negara asing yang akan memasuki Indonesia, baik secara langsung maupun transit di negara asing, untuk sementara dilarang memasuki Indonesia kecuali pemegang visa diplomatik dan visa dinas yang terkait kunjungan resmi pejabat asing setingkat menteri ke atas dengan penerapan protokol kesehatan yang sangat ketat" , selanjutnya pada butir dilanjutkan "Pelaku perjalanan Internasional yang berstatus WNA dari luar negeri dikecualikan untuk:

1. Pemegang izin tinggal diplomatik dan izin tinggal dinas,

2. Pemegang kartu izin tinggal terbatas (KITAS) dan kartu izin tinggal tetap (KITAP); dan, WNA dengan pertimbangan dan izin khusus secara tertulis dari Kementerian/Lembaga." Surat Edaran Dirjen Imigrasi Nomor IMI-0103.GR.01.01 Tahun 2021 tentang Pembatasan Sementara Masuknya Orang Asing ke Wilayah Indonesia dalam Masa Pandemi Covid-19 juga mencantumkan ketentuan serupa.

Dari kasus tersebut diketahui, menurut sesuai surat edaran sebelumya yang mengacu kepada Peraturan Menteri Hukum dan Hal Asasi Manusia RI Nomor 11 Tahun 2020 tentang Pelarangan Sementara Orang Asing Masuk Wilayah Republik Indonesia. Memanglah melarang dan membatasi orang asing yang diperbolehkan masuk ke Indonesia mulai dari 2 april 2020 sampai dengan waktu yang belum ditentukan. Dimana pengecualian untuk WNA yang punya Visa Dinas, Visa Diplomatik, ITAP, ITAS, Alat Angkut, WNA akan diperkerjakan pada projek negara, serta untuk keperluan genting untuk alat Kesehatan dan medis. Lalu selanjutnya WNA dapat diberi dan menerima izin tinggal darurat dan tak harus memberikan permohonan ke UPT imigrasi.

Merujuk dari Surat Edaran Nomor Imi-Gr.01.012325 Tahun 2020 Tentang Pelarangan Sementara Orang Asing Masuk Wilayah Negara Republik Indonesia pada dasarnya dari kasus tersebut. Warga negara asing yang berjumlah 153 dengan rincian 150 orang menggunakan ITAS dan ITAP serta 3 orang menggunakan Visa Diplomatik sudah memenuhi peraturan yang telah ditetapkan Pada Surat Edaran Nomor Imi-Gr.01.012325 Tahun 2020 Tentang Pelarangan Sementara Orang Asing Masuk Wilayah Negara Republik Indonesia. Dan dari hal itu imigrasi telah melakukan pengawasan dan penegakan hukum dimana pengawasan tersebut dengan menerapkan kebijakan Selective Policy dimana hanya orang asing yang dapat memasuki Indonesia dengan hal yang memberikan pengaruh baik dan dapat menaati hukum yang berlaku diindonesia dan mememberikan manfaat kepada negara. Akan tetapi memang polemik dimana masyarakat Indonesia yang saat ini hanya mengetahui bahwasanya masyarakat Indonesia memiliki statement yang berbeda mengenai WNA china tersebut yang menuju ke NKRI. dimana china merupakan Kawasan yang merupakan awal mula dimana virus Covid-19 ini menyebar.

Maka imigrasi sebagai penjaga pintu gerbang negara wajib melindungi negara dari ancaman-ancaman tersebut dapat dikatakan sebagai penjaga kedaulatan negara, salah satunya berperan dalam pembatasan akses masuk warga negara asing keindonesia, untuk mengutamakan keselamatan rakyat Indonesia. Akan tetapi Imigrasi juga memiliki peran lain yaitu sebagai fasilitator pembangunan, disini terdapat sebuah dualism dimana satu sisi Imigrasi sebagai penjaga kedaulatan negara dan imigrasi sebagai fasilitator pembangunan. Maka untuk mengatasi hal tersebut imigrasi menerapkan sebuah cara pengawasan yaitu selectiv policy dimana hanya warga negara asing yang tidak mengacam kedaulatan dan memberikan manfaat kepada negara dan dapat mematuhi hukum diindonesia yang berlaku. Maka kedatangan 153 orang china tersebut tidak serta merta tidak memberikan manfaat kepada negara Indonesia. Akan tetapi ancaman terhadap virus menjadi sebuah tantangan dan resiko dari buah manfaat pengizinan masuk 153 warga negara china tersebut.

Dalam menghadapi tantangan tersebut, imigrasi Indonesia juga menerapkan standar protocol Kesehatan yang telah dibuat oleh mentri Kesehatan dan satgas covid-19. Dalam Permenkes Nomor HK.01.07/MENKES/328/2020 Panduan Pencegahan dan Pengendalian Corona Virus Disease (Covid-19) di kantor dan tempat kerja industri yang membutuhkan perkantoran dan kawasan industri untuk me protokol kesehatan yang ketat, seperti menggunakan thermogun, menyediakan perkakas tangan, remote control sosial, pemantauan, memakai masker, perlu menggunakannya. Semua ruang kantor, termasuk Kantor Imigrasi, juga menerapkan protokol kesehatan yang tercantum di atas, termasuk layanan visa dan izin tinggal. Penerapan protokol kesehatan yang diamanatkan Kementerian Kesehatan diharapkan dapat menghasilkan angka penyebaran Covid-19.

Intruksi dari Menkes terdapat juga Surat Edaran Nomor Imi-Gr.01.01- 0946 Tahun 2020 Tentang Pelaksanaan Tugas dan Fungsi Keimigrasian Dalam Masa Tatanan Normal Baru. Dimana aturan baru tersebut diharapakan menurunkan merabaknya Covid-19 di lingkungan kerja imigrasi dan tetap dapat menjalankan aktifitas layanan dan supermasi hukum dibidang keimigrasian dengan menerapkan peraturan dan protokol Kesehatan yang berlaku. Akan tetapi dari Surat edaran tersebut lebih terkonsentrasi kepada 
penerapannya dalam kantor keimigrasian dibidang pelayanan dokumen perjalanan. Tidak dijelaskan secara mendetil dalam masalah adaptasi kebiasaan baru untuk penegakan hukum dan juga pengawasan terhadap orang asing. Dalam surat edaran juga Surat Edaran Nomor ImiGr.01.01- 0946 Tahun 2020 Tentang Pelaksanaan Tugas dan Fungsi Keimigrasian Dalam Masa Tatanan Normal Baru, ini lebih ditekankan dalam pelayanan dokumen perjalanan bagi WNI atau WNA. Seharusnya terdapat surat edaran yang juga memberikan aturan yang harus dilaksanakan bagi penegak hukum keimigrasian dan pengawasannya kepada orang asing dimasa pandemic seperti ini.

Karena dari kasus tersebut dimana orang asing warga negara china tersebut imigrasi hanya melakukan pengawasan secara dokumen dimana saat mereka dating dan penegakan hukum dilakukan saat itu dalam pengawasan dokumen dan juga menerapkan selectiv policy. Maka pengawasan terhadap warga negara asing yang sesuai dengan protocol hanya pada konter kedatangan selebihnya belum ada aturan surat edara yang mengatur tentang pengawasan dan penegakan hukumnya yang diatur dalam prokes tersebut. Lantas fungsi keimigrasian tersebut tidak berjalan dengan efektif, dimana hal tersebut dapat menyebabkan ketidakstabilan. Maka diperlukan sebuah aturan baru ataupun SOP untuk mengatur bagaimana pengawasan dan penegakan hukum dalam masa pandemic..

\section{SIMPULAN}

Penegakan hukum dan pengawasn keimigrasian di masa kenormalan baru tetap wajib dilaksanakan dengan tepat dan sesuai target serta tidak memberikan pengaruh penambah Covid-19 di Indonesia. Dimana tugas sebagai petugas imigrasi semakin berat karena dalam penegakan hukum dan pengawasan pada masa pandemic akan lebih memberikan resiko terpaparnya virus. kontrol dan pengupayaan hukum imigrasi pada WNA belum mengalami perubahan dalam penyesuaian masa pandemic dan belum terdapatnya sop dan protocol khusus dibidang penegakan hukum dan pengawasan keimigrasian dimasa pandemic seperti saat ini. Dan dalam kasus 153 warga negara china tersebut imigrasi hanya menerapkan kebijakan pengawasan dan penegakan hukum dengan menerapkan selectiv policy dimana dilakukan dikonter kedatangan. Dan belum adanya SOP pelaksanaan tentang penegakan hukum dan pengawasan inteljen maupun terbuka dalam masa pandemic yang berguna untuk penyesuaian normal baru. Pemerintah hanya menerapkan kebijakan berbeda terkait layanan keimigrasian agar dapat terus berfungsi secara efektif tanpa menganggap remeh Covid-19. Bagi petugas imigrasi dalam penyediaan layanan ataupun pemohon yang menerima layanan harus mematuhi protocol kesehatan. Akan tetapi belum ada SOP bagi petugas yang melaksanakan penegakan hukum dan pengawasan inteljen maupun operasi terbuka

\section{DAFTAR PUSTAKA}

Kemenkes RI. (2020). Pedoman dan Pencegahan Coronavirus (COVID- 19). Jakarta: Kementrian Kesehatan RI.

MA Syahrin, "Teori Kebijakan Selektif” (Petak Norma, 26 September 2018)

Pitaloka, H., Al Umar, A. U. A., Hartati, E. R., \& Fitria, D. (2020). The economic impact of the COVID19 outbreak: Evidence from Indonesia. Jurnal Inovasi Ekonomi, 5(02).

Soekanto, Soerjono. (2014). Faktor-faktor yang Mempengaruhi Penegakan Hukum. Jakarta : PT. RajaGrafindo Persada.

Syahrin, M.A. (2020). Penegakan Hukum Keimigrasian Indonesia dalam Keadaan Darurat (Covid 19). Research Gate. DOI: 10.1140/RG.2.2.17315.48160/1.

Penjelasan Umum Undang Undang Nomor 6 Tahun 2011 tentang Keimigrasian.

Permenkes Nomor HK.01.07/MENKES/328/2020 Panduan Pencegahan dan Pengendalian Corona Virus Disease (Covid-19)

Peraturan Menteri Hukum dan Hal Asasi Manusia RI Nomor 11 Tahun 2020 tentang Pelarangan Sementara Orang Asing Masuk Wilayah Republik Indonesia.

Surat Edaran Nomor Imi-Gr.01.01- 2325 Tahun 2020 Tentang Pelarangan Sementara Orang Asing Masuk Wilayah Negara Republik Indonesia

Surat Edaran Dirjen Imigrasi Nomor IMI0103.GR.01.01 Tahun 2021 tentang Pembatasan Sementara Masuknya Orang Asing ke Wilayah Indonesia dalam Masa Pandemi Covid-19

Surat Edaran Nomor Imi-Gr.01.01- 0946 Tahun 2020 Tentang Pelaksanaan Tugas dan Fungsi Keimigrasian Dalam Masa Tatanan Normal Baru

Surat Edaran: IMI-GR.01.01-1102 Tahun 2020 tentang Pelayanan Izin Tinggal Keimigrasian di tatanan kenormalan baru

Suryokumoro, Herman. (2020). Aktualisasi Fungsi Keimigrasian dalam Aspek Keamanan sebagai Upaya Integral Penanganan Pandemi Covid-19 Di Indonesia..

Undang-Undang Nomor 6 Tahun 2011 tentang Keimigrasian 